\title{
Effect of Lactate and Starter Inoculum on Biogas Production from Fresh Maize and Maize Silage
}

\author{
Preseela Satpathy ${ }^{1,2}$, Sven Steinigeweg1, Eike Siefert1, Heribert Cypionka ${ }^{2 *}$ \\ ${ }^{1}$ EUTEC Institute, University of Applied Sciences Emden/Leer, Emden, Germany \\ ${ }^{2}$ Institute for Chemistry and Biology of the Marine Environment (ICBM), University of Oldenburg, Oldenburg, Germany \\ Email: ^heribert.cypionka@icbm.de
}

How to cite this paper: Satpathy, P., Steinigeweg, S., Siefert, E. and Cypionka, H. (2017) Effect of Lactate and Starter Inoculum on Biogas Production from Fresh Maize and Maize Silage. Advances in Microbiology, 7, 358-376.

https://doi.org/10.4236/aim.2017.75030

Received: March 1, 2017

Accepted: May 20, 2017

Published: May 23, 2017

Copyright $\odot 2017$ by authors and Scientific Research Publishing Inc. This work is licensed under the Creative Commons Attribution International License (CC BY 4.0).

http://creativecommons.org/licenses/by/4.0/

\section{c) (†) Open Access}

\begin{abstract}
Lactate is a key intermediate during anaerobic digestion of carbohydrates; however, it fails to receive significant consideration in biogas plants. We examined the influence of lactic acid on biogas production. Two commonly used feeds, fresh maize and maize silage, were selected as substrates due to their difference in lactic acid contents. Additionally, inocula from an agriculture-based biogas plant, a waste water treatment plant and a standardised laboratory reactor were selected to investigate the impact of starter culture on the process. Experiments demonstrated increased total biogas yield of up to $45 \%$ in the lactate-rich maize silage over the lactate-devoid fresh maize, but only in cases where the starting inocula had been previously exposed to lactic acid. Our findings suggest lactic acid is a significant intermediate in biogas production and merits consideration. Additionally, the ability of the starter inoculum to utilize lactic acid is an important factor in process optimization and enhanced biogas production.
\end{abstract}

\section{Keywords}

Biogas, Lactic Acid, Maize, Silage, Starter Inoculum

\section{Introduction}

Industry creates large quantities of nutrient-rich effluents that, if released into the environment, can cause environmental pollution and disturb the ecosystem [1]. A common method for treatment of these wastes is their conversation to biogas in biogas facilities via anaerobic bacterial processes [2]. Biogas production generates methane that can act as a replacement for fossil fuels for powering homes, industry and vehicles [3]. As a result, biogas production can have a posi- 
tive impact not only on the environment, but also to industry by reducing costs imposed by government for waste release, increasing revenue by selling biogas into the grid and financial savings by powering their own facilities with energy produced [4]. Due to the increasing number of biogas plants in many parts of the world, a continual improvement in technology and increased understanding of the whole process of anaerobic digestion is necessary. When the behavior of the process can be predicted, the production can be optimized and problems such as process failures, reactor break down and low biogas yields can be prevented [5]. Biofuels research, standard procedures and mathematical modeling can assist in increasing and improving yields, therefore is of utmost importance to industry [6].

\subsection{Influence of Lactic Acid on Biogas Production}

Lactic acid has been described previously in literature as a significant acid generated in the anaerobic digestion of ensiled energy crops such as maize silage or fermented vegetable wastes [7] [8]. Mrůzek and Groda [9] found that the methane content in biogas positively correlated with lactic acid contents. In dairy effluents, large quantities of lactic acid have been reported as a result of lactose degradation [10] [11]; however the role of lactic acid in many biogas producing facilities is still largely ignored. It is also often absent in predictive mathematical models and software such as Aspen, Simba, Activated Sludge Model No. 1 (ASM1), Anaerobic Digestion Model No.1 (ADM1) etc. used for simulating biogas plants.

Biogas reactor failures have been reported previously in acidification reactors during transient overload conditions as a direct result of lactic acid accumulation [12] [13]. Due to the low acid dissociation constant of lactic acid $\left[\mathrm{pK}_{\mathrm{a}}=\right.$ 3.86], its accumulation can lead to dramatic drop in $\mathrm{pH}$ further resulting in breakdown of the whole digestion process [14]. Zhang et al. [15] recommended avoiding the accumulation of lactic acid to improve anaerobic digestion of kitchen waste-fueled biogas digesters.

Maize and its silage are the most ensiled crops in the world, widely used for biogas generation due to their high carbohydrate content and easy cultivability [16]. Fresh maize normally bears no lactate, however maize silage has been reported to contain lactic acid up to $10 \%$ dry mass [17]. These two carbohydrate-rich substrates were selected for this study due to their relevance to industry and difference in lactic acid concentrations. Additionally, lactic acid as a sole substrate was tested to assess its impact on biogas yield.

\subsection{Impact of Inoculum Source on Biogas Production}

Anaerobic bacteria have a major role in the fermentation process, particularly in the hydrolysis of carbohydrates to monosaccharides. These monosaccharides are degraded to lactic acid, which is then converted to $\mathrm{H}_{2}$ and acetate for further conversion to biogas [18].

The structure and activity of the microbial community involved in fermenta- 
tion often depends on the original inoculum source and starter biomass, as well as the operational and environmental conditions [19] [20] [21] [22]. Bacterial communities in biogas plants adapt to the substrates fed [23]. Hence, biological behavior becomes very specific to that particular plant, further influencing the biogas production [24].

Three different inocula were selected for testing in this study; one from an agriculture-based biogas plant, one from a waste water treatment plant, and a final inoculum from a continually controlled and monitored standard reactor. The aim of this research was to investigate the role of starter inocula, lactic acid and substrate type on biogas yield, with a view to improving processes and predictive models of biogas systems.

\section{Materials and Methods}

\subsection{Substrates}

Fresh maize and maize silage were sourced from the same farm in the Emden region of Lower Saxony, Germany. Fresh maize plant was freshly harvested and roughly shredded into $1 \mathrm{~cm}$ pieces and prepared maize silage was collected from the same farmer. All samples were frozen at $-20^{\circ} \mathrm{C}$ for later analysis.

\subsection{Sources of Inocula}

\subsubsection{Agriculture Biogas Plant Inoculum}

The agriculture biogas plant bacterial inoculum was obtained from EWE biogas plant, Wittmund, Lower Saxony, Germany [25]. The EWE biogas plant operates with cattle manure and organic wastes from farms and food industries. Inoculum from the anaerobic digester was collected fresh and used within 5 hours for each experiment.

\subsubsection{Wastewater Treatment Plant Inoculum}

The wastewater treatment plant inoculum was obtained from the anaerobic digester of the municipal sewage treatment plant of Papenburg, Lower Saxony, Germany [26]. Inoculum was freshly collected and used within 5 hours for each experiment.

\subsubsection{Standard Reactor Inoculum}

A standard inoculum was prepared in a $12 \mathrm{~L}$ Plexiglass Continuous Stirred Tank Reactor (CSTR) with a working volume of $8 \mathrm{~L}$, and was maintained at $38^{\circ} \mathrm{C}$. Initial inoculum was sourced from the EWE Wittmund biogas plant [25]. The primary reactor feed was composed of energy source mixture and a modified anaerobic cultivation medium by Angelidaki and Sanders [27] (Table 1). The energy source comprised of the organic components starch, rapeseed oil and casein protein in a 2:3:3 ratio, with a final mass of $80 \mathrm{~g}$. To this, the following stock solutions were added: (A), $10 \mathrm{~mL}$; (B), $1 \mathrm{~mL}$; and (C), $1 \mathrm{~mL}$. This feed was filled in a volumetric flask and was made up to $1 \mathrm{~L}$ with distilled water (Table 1). Further, these contents were added to the Sørenson phosphate buffer solution $(0.133 \mathrm{M}, \mathrm{pH} 7.4$; Table 1$)$ in a ratio of $1: 1.5$ to be fed into the reactor. The feed 
Table 1. Standard bioreactor primary reactor feed composition.

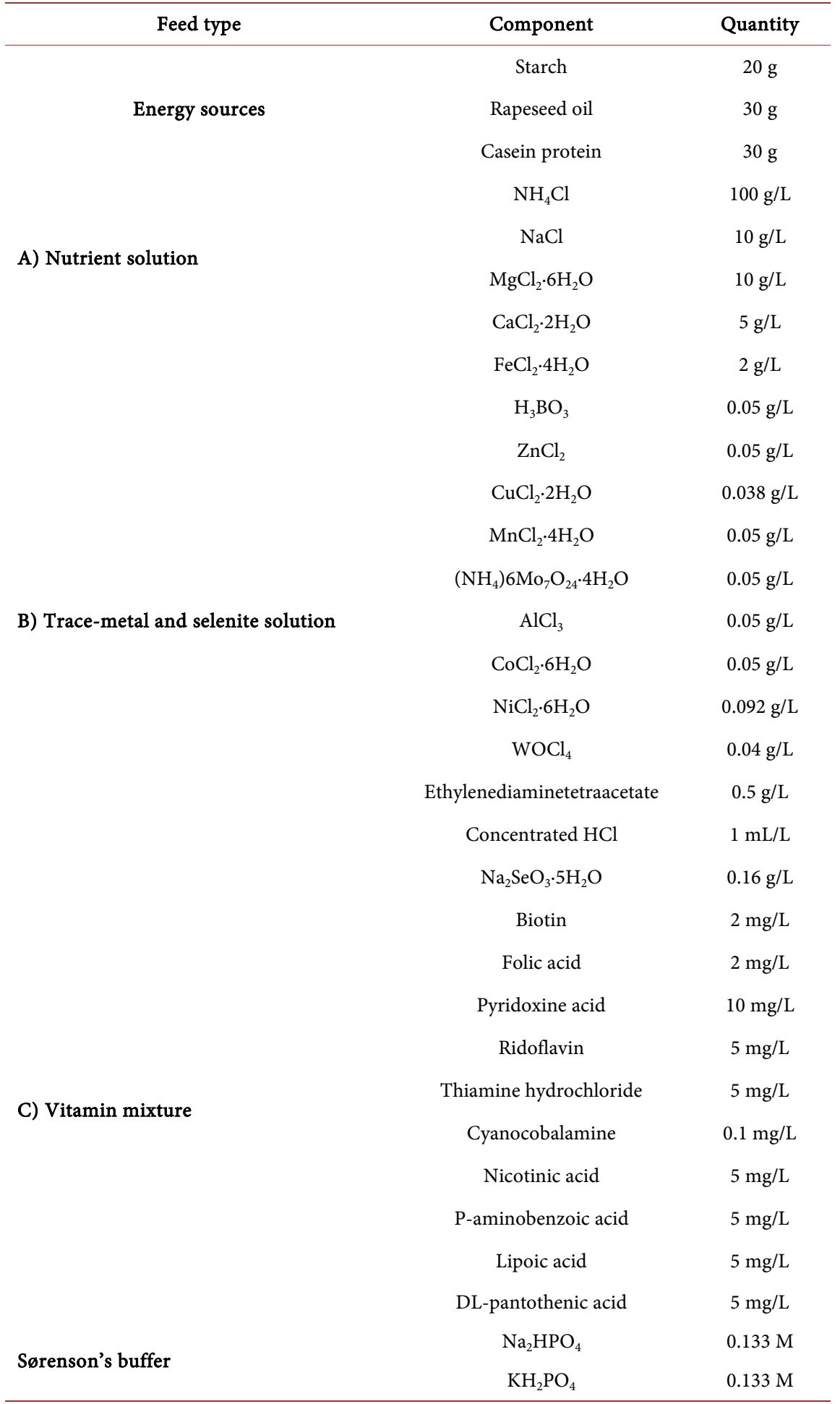

was adjusted to a final $\mathrm{pH}$ of 7.4 with $\mathrm{NaOH}$. The prepared medium was further required to be free from contamination during feeding and storage which was achieved by reducing the $\mathrm{pH}$ to 4.0 using $5-6 \mathrm{~mL}$ formic acid (conc. $\geq 95 \%$ ). This prepared standard medium was fed into the reactor hourly, with a retention time of 18 days. 
The inoculum collected from this reactor was used for experimentation after 5 volume changes to ensure no influence of the EWE biogas plant starter microbial cultures. The $16 \mathrm{~S}$ rRNA sequencing was undertaken to ensure a difference in the microbial community composition of the starter inoculum from EWE biogas plant the final standard reactor population. The standard bacterial inoculum was grown in this continuous culture and was collected from the outlet of the reactor. RITTER Milligas ${ }^{\oplus}$ counter provided continuous monitoring of biogas production, and methane and carbon dioxide was measured via BlueSens gas sensors from the outlet port of the reactor.

\subsection{Chemical Analyses}

\subsubsection{Dry Matter (DM) and Volatile Solids (VS) of Maize and Inocula}

Known quantities of sample were taken and dried in an oven at $105^{\circ} \mathrm{C}$. The volatile solids were quantified by combusting dried samples at $550^{\circ} \mathrm{C}$ for $4 \mathrm{~h}$ [28].

\subsubsection{Determination of Lactate Content of Maize and Inocula}

D-and L-lactic acid were determined using enzymatic test kits from R-Biopharm. Sample preparation included filtering for inocula samples, and Carrez clarification for maize samples. Tests were then performed as per manufacturer's instructions. The limits of detection by the enzymatic test were $1-60 \mathrm{mg} / \mathrm{L}$.

\subsubsection{Determination of Volatile Fatty Acids}

A series of volatile fatty acids (VFA) standards for the calibration curves were prepared for Gas Chromatographic (GC) analysis using seven aqueous solutions of acids: acetic, propionic, butyric, isobutyric acid, valeric acid, isovaleric acid and lactic acid. These calibration samples were centrifuged for 3 minutes and adjusted to $\mathrm{pH} 2$ using $0.1 \mathrm{~N} \mathrm{HCl}$, and spanned a concentration range of 1 to 100 g/L. GC analyses were performed on a GC 7820 Agilent gas chromatograph equipped with a flame ionization detector and an INNOPEG-FFAP column (30 $\mathrm{m}, 0.25 \mathrm{~mm}$ I.D., $0.25 \mu \mathrm{m}$ film thicknesses, CS, Germany). This column is a high polar polyethylene glycol column suitable for separation of free fatty acids in aqueous extracts. The analyses were performed using an isothermal temperature program with the injector and detector temperatures maintained at $180^{\circ} \mathrm{C}$. The carrier gas was nitrogen. In each case a $1 \mu \mathrm{L}$ of sample was injected with a flow splitting 1:50. Samples for analysis were centrifuged for 3 minutes and adjusted to $\mathrm{pH} 2$ using $0.1 \mathrm{~N} \mathrm{HCl}$.

\subsection{Experimental Setup for Biogas Determination from Maize and Silage}

Batch experiments were prepared in accordance with the German standard VDI 4630 [28]. In each $1100 \mathrm{~mL}$ bottle, $490 \mathrm{~g}$ of inoculum was mixed with $10 \mathrm{~g}$ of wet weight substrate. This inoculum ratio ensured an authentic biogas power plant feeding scenario [5] [20]. The two substrates had comparable dry mass content. 
Controls (reference) were prepared by mixing $10 \mathrm{~g}$ of distilled water with $490 \mathrm{~g}$ of inoculum. Biogas production was measured with an ANKOM's (N1v0, 4RF2; RFS\#194) gas production system with readings transmitted wirelessly to a computer every hour. Pressure values were further used to calculate the biogas production yield. This experimental setup was performed with the three different types of inocula, and experiments were prepared in triplicate.

\subsection{Biogas Production with Lactic Acid as a Sole Substrate}

The three inocula were checked for the biogas production with lactic acid as the sole substrate. D/L-lactic acid from Sigma Aldrich was used for the experiments to check for its degradation with the different sources of inoculum. Batch experiments were performed with $10 \mathrm{mM}(0.9 \mathrm{~g} / \mathrm{L})$ of lactic acid using ANKOM wireless gas monitors as described previously. The average values for biogas production were presented. Lactic acid with its strong $\mathrm{pKa}$ value showed a remarkable impact by decreasing the $\mathrm{pH}$ of the inoculum. Therefore, the $\mathrm{pH}$ was adjusted to the original $\mathrm{pH}$ for each inoculum using $\mathrm{NaOH}$. Gas chromatographic analyses were performed daily with samples taken from the side vent of the bottle.

\subsection{Biogas Production with Optimized Feed, Lactic Acid as a sole Substrate and Standard Reactor Inoculum}

Primary reactor feed used for the standard reactor was optimized to attain maximal biogas production in batch experiments. The energy source concentration required to achieve maximal biogas production was maize starch, rapeseed oil and casein protein with the concentrations $1.3 \mathrm{~g} / \mathrm{L}, 2.0 \mathrm{~g} / \mathrm{L}$ and $2.0 \mathrm{~g} / \mathrm{L}$ respectively. Any concentration of energy sources above these proved to be inhibitory to biogas production. A lactic acid concentration of $10 \mathrm{mM}$ neutralized D/L-lactic acid was used to demonstrate the impact of lactic acid as a sole substrate. These were made up to a final volume of $100 \mathrm{~mL}$ with standard inoculum for the comparative study. Experiments with $150 \mathrm{mM}$ and $250 \mathrm{mM}$ lactic acid were further performed in order to determine the inhibitory concentration. The reference for this experiment was $100 \mathrm{~mL}$ of standard inoculum. Batch experiments were performed for 3 hours using ANKOM wireless gas monitors. An activity curve was created in order to infer an approximate contribution of a small fraction of lactic acid to the total activity of the standard reactor with the optimized feed. The experiments were performed in triplicates, with readings determined every 5 minutes and the average presented.

\section{Results and Discussion}

\subsection{Lactic Acid in Substrates}

Fresh maize and silage were considered for the experiments due to the major differences in their lactate content [29]. This difference in concentration was confirmed by the lactic acid analysis. Analysis revealed a negligible amount of Dand L-lactic acid in fresh maize, and 4.8\% DM in maize silage (Table 2). Along 
Table 2. Acid content of fresh maize and maize silage.

\begin{tabular}{cccccc}
\hline & $\begin{array}{c}\text { DM } \\
(\%)\end{array}$ & $\begin{array}{c}\text { VS } \\
(\% \mathrm{DM})\end{array}$ & $\begin{array}{c}\text { D-Lactic acid } \\
(\% \mathrm{DM})\end{array}$ & $\begin{array}{c}\text { L-Lactic acid } \\
(\% \mathrm{DM})\end{array}$ & $\begin{array}{c}\text { Acetic acid } \\
(\% \mathrm{DM})\end{array}$ \\
\hline Fresh maize & 26 & 95 & 0.005 & 0.004 & 0 \\
Maize silage & 28.5 & 97.6 & 2.8 & 2.0 & 0.6 \\
\hline
\end{tabular}

with this, minor amounts of acetic acid (accounting to nearly $12.5 \%$ of that of lactic acid) were detected in maize silage as well.

\subsection{Lactic Acid in Starter Inocula}

Inocula from agriculture-based biogas plant and the standard reactor showed the presence of L-lactic acid, suggesting these inocula may contain microbial populations adapted to survive in and utilise the substrate. Inoculum from the waste water treatment plant showed a negligible content of D- and L-lactic acid (Table 3). This could be explained by smallamounts of carbohydrates in the waste water source [30].

\subsection{State of the Standard Reactor}

A volume of 3.1L biogas was generated per day, with a total methane content of $68 \%$. In the steady state, the metabolite showing the highest concentration was acetic acid $(20 \mathrm{mM})$ which is a direct precursor of methane. Propionic acid (3 $\mathrm{mM})$ and lactic acid $(1 \mathrm{mM})$ were also detected. Starch can be enzymatically hydrolyzed to glucose and further fermented to lactic acid by lactic acid bacteria [31]. Therefore, presence of lactic acid in our standard reactor suggested starch fermentation and high consumption rate of the starch in the reactor [32]. Acetic acid was initially chosen to lower the $\mathrm{pH}$ to 4.0 to ensure sterility, however this led to its accumulation in the reactor and resultant $\mathrm{pH}$ drop issues. This problem was rectified byinstead selectingformic acid as an alternative. Sørenson's buffer $(0.133 \mathrm{M})$ was also found to be effective in maintaining $\mathrm{pH}$ stability in the reactor.

The 16S rRNA gene fragments of both bacteria and archaea revealed a clear difference in the microbial community composition of the starter inoculum from EWE biogas plant had BacteroidesandMethanosarcina, and the final standard reactor population, which was comprised of Firmicutesand Methanomethylovorans as predominant groups [33].

\subsection{Biogas Production with Fresh Maize and Maize Silage in Batch Experiments}

In experiments using agriculture-based inoculum, maize silage showed enhanced biogas production compared with fresh maize (Figure 1(a)). This result correlates with previous studies of [34] [35] which report an enhanced biogas production rate with ensiled crops than fresh materials. There are several possible explanations for this. The hydrolyzed structure of silage can improve nutrient availability and the release of sugars to methanogens [29]. Sugars are pri- 


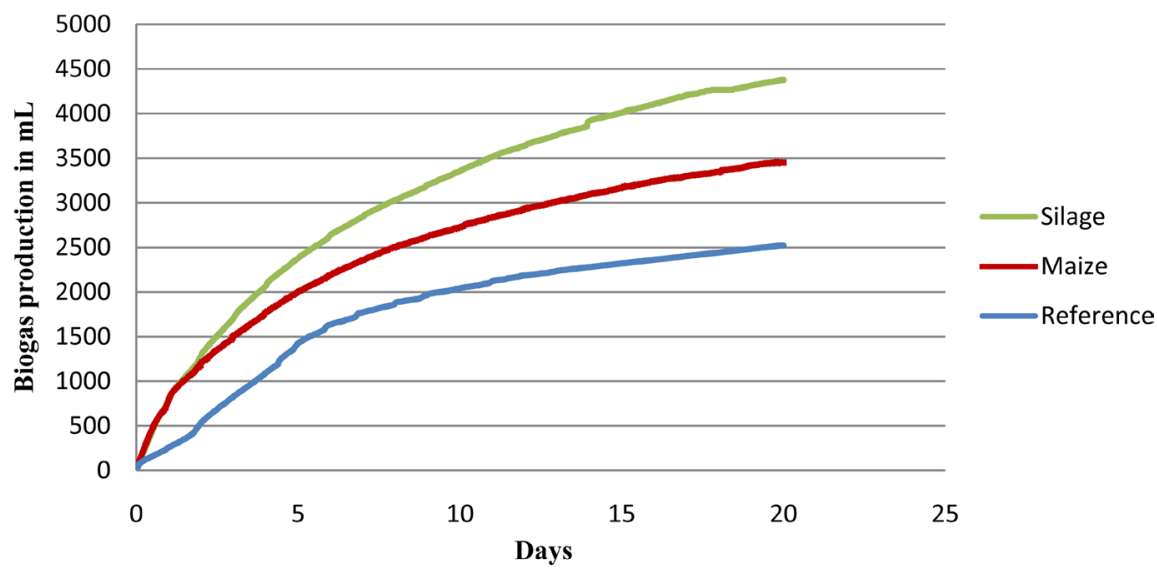

(a)

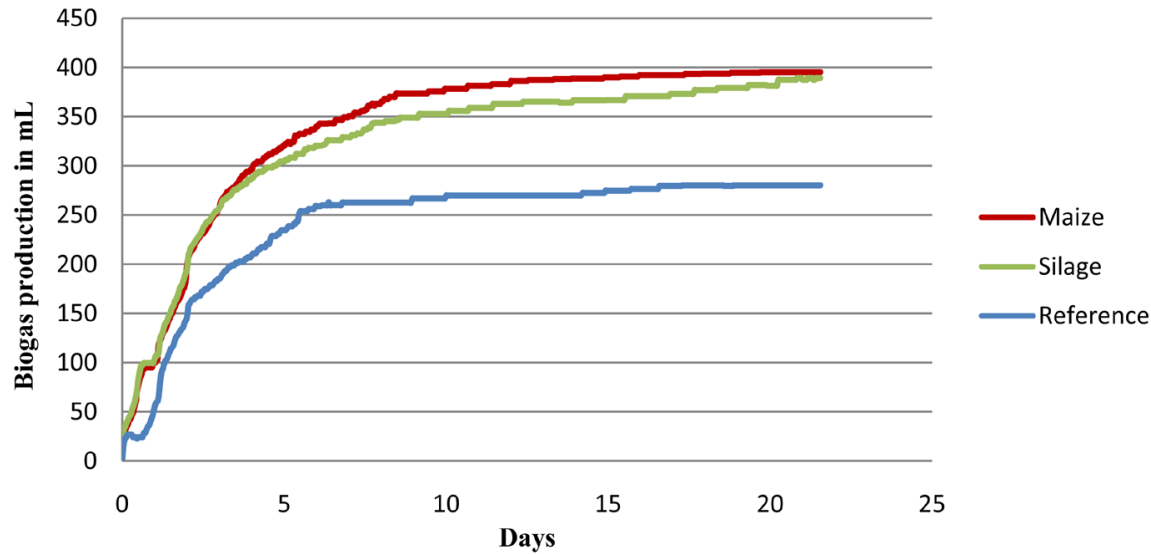

(b)

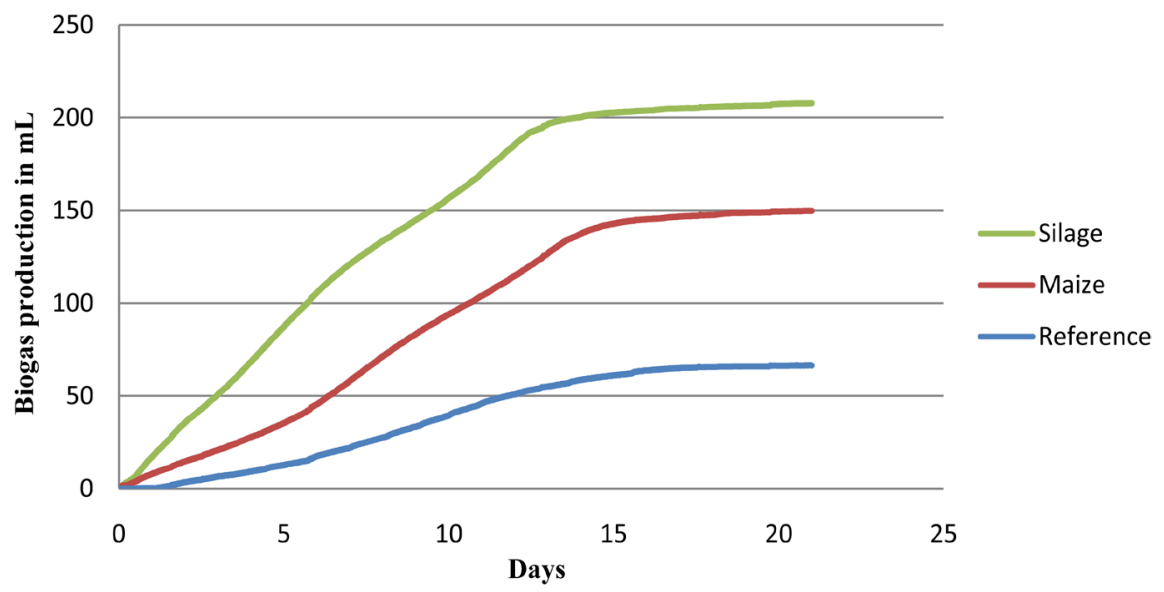

(c)

Figure 1. (a) Biogas production with fresh maize and silage with inoculum from agriculture based biogas plant. Pure inoculum mixed with water instead of substrate was considered as reference; (b) Biogas production with fresh maize and silage with inoculum from waste water treatment plant. Pure inoculum mixed with water instead of substrate was considered as reference; (c) Biogas production with fresh maize and silage tested with inoculum from standard reactor prepared in the laboratory. Pure inoculum mixed with water instead of substrate was considered as reference. 
Table 3. Lactic acid content and FOS/TAC analysis of starting inocula.

\begin{tabular}{cccccc}
\hline Inoculum from & $\begin{array}{c}\text { DM } \\
(\%)\end{array}$ & $\begin{array}{c}\text { VS } \\
(\% \mathrm{DM})\end{array}$ & $\begin{array}{c}\text { D-Lactic acid } \\
(\% \mathrm{DM})\end{array}$ & $\begin{array}{c}\text { L-Lactic acid } \\
(\% \mathrm{DM})\end{array}$ & $\begin{array}{c}\text { Acetic acid } \\
(\% \mathrm{DM})\end{array}$ \\
\hline Agriculture-based biogas plant & 4.9 & 66.2 & 0.01 & 0.28 & 0.02 \\
Wastewater treatment plant & 3.0 & 99.3 & 0 & 0.03 & 0.08 \\
$\begin{array}{c}\text { Standard reactor } \\
\text { Stand }\end{array}$ & 1.8 & 26.7 & 0.02 & 0.66 & 0.01 \\
\hline
\end{tabular}

marily fermented to lactic acid which are further transformed to acetate and hydrogen that can be used for methane formation [18]. Additionally, silage itself contains acids such as acetic and lactic acid which are easily degradable substrates for the microorganisms. Improved biogas production with maize silage has been reported previously as a result of heterofermentive lactic acid fermentation and presence of other organic acids [36].

The inoculum from the waste water treatment plant failed to show any considerable difference in biogas production between the substrates (Figure 1(b)). The partial hydrolysis of maize and the presence of lactic acid were not the only precondition for enhanced biogas production. While in agriculture-based biogas plants the bacteria are more exposed to carbohydrate-rich substrates and are adapted to lactate, those in sewage waste water treatment plants might not be adapted to it, suggesting it is a non-adapted inoculum. Composition of starter inocula and the culture conditions have been reported to influence the methane production due to differences in the microbial composition [37] [38]. The role of the starter inoculum could thus be noticed to play a significant role in having an impact on the biogas production.

More biogas was produced from silage than fresh maize in the standard reactor experiments (Figure 1(c)). GC analysis further revealed an increased total acetic acid content during the degradation of silage compared to fresh maize (Appendix I). This might be due to the undergoing heterofermentative lactic acid fermentation [18]. Lactic acid was also found in the inoculum and this could indicate the presence of lactate producing, and probably also lactatedegrading microbial species in the reactor. The standard reactor was fed with maize starch as one of the major energy sources and this could explain its adaptability to maize and its degradation products.

The reference samples had also shown substantial biogas production in the absence of added fresh maize and maize silage. This could be due to the intermediate organic acid contents in those samples. Acetic, propionic, lactic, butyric and valeric acids were detected in all inocula (presented in Appendix II). Acetic acid was found to be dominant in each case, with concentrations in the range of $0.5-1.6 \mathrm{~g} / \mathrm{L}$ across each of the inocula. The biogas produced during batch experiments with these reference samples was subtracted and is presented (Table 4) in order to provide an accurate contribution of biogas production with fresh maize and silage with each inoculum. This facilitated a clear comparison of the gas generated only from the substrates. 
Table 4. Biogas production yield tested with different source of inocula with maize and its silage as substrates.

\begin{tabular}{cccc}
\hline Inoculum source & $\begin{array}{c}\text { Biogas production } \\
\text { from fresh } \\
\text { maize }(\mathrm{mL})\end{array}$ & $\begin{array}{c}\text { Biogas production } \\
\text { from maize } \\
\text { silage }(\mathrm{mL})\end{array}$ & $\begin{array}{c}\text { Difference in biogas } \\
\text { production with silage } \\
\text { and fresh maize }(\mathrm{mL})\end{array}$ \\
\hline $\begin{array}{c}\text { Agriculture-based } \\
\text { biogas plant }\end{array}$ & 1010 & 1838 & 838 \\
$\begin{array}{c}\text { Waste water } \\
\text { treatment plant }\end{array}$ & 107 & 101 & -6 \\
Standard Reactor & 85 & 142 & 57 \\
\hline
\end{tabular}

Factors such as $\mathrm{pH}$, alkalinity, volatile fatty acids (VFA) have also been identified to influence the biogas production [2]. Inhibition at lower $\mathrm{pH}$ by free organic acids such as acetic, propionic, butyric and valeric acids have been reported by [39]. During our experiments, however, the addition of silage did not influence the $\mathrm{pH}$ remarkably. Inhibition by acidification was not observed in our batch reactor experiments. The acids were consumed fairly and a $\mathrm{pH}$ above 7 was observed for all the samples towards the end of the experimentation.

Maize and silage differ significantly in terms of lactic acid content as discussed previously. The silage is preserved against degradation by bacterial contamination as a result of the high concentration of lactic acid and the corresponding low $\mathrm{pH}$, and also bears a more hydrolyzed structure [34]. There have been varying discrepancies in previous research surrounding the differences in biogas production with maize and its silage. With some reports demonstrating no difference in the biogas production with fresh and ensiled maize [40] [41], the others report an enhanced biogas production with maize silage. Investigations by [29] and [30] report an increased methane yield by about $25 \%$ and $14.6 \%$ respectively with maize silage compared to green, fresh maize. Sträuber et al. [7] remark ensilage process serves as a pre-treatment measure for enhanced biogas production due to its hydrolyzed structure and acidogenic fermentation products. Works from [42] and [35] also show,enhanced methane production with lactate-rich silage. Such contradictions could possibly be due to the different nature and microbial composition of the inoculum. Numerous studies show that the microbial communities and their behavior in biogas reactors are controlled mainly by the starter inocula [20] [24] [37] [38]. Due to the importance of starter inoculum on the system, using silage as a primary substrate may have varying results in biogas production, as this is dependent whether the microbial community is adapted to lactic acid or not.

\subsection{Biogas Production with Lactic Acid as a Sole Substrate}

Biogas production from lactic acid as a sole substrate was measured to assess the impact of the acid alone on the system. Biogas was produced from lactic acid in cases where the microbial community present has the capacity to utilize the substrate. Maximum biogas production was observed by the inoculum from agriculture-based biogas plant $(605 \mathrm{~mL})$, followed by the inoculum from the stan- 
dard reactor $(460 \mathrm{~mL})$ and the minimum biogas production observed in the inoculum from waste water treatment plant $(210 \mathrm{~mL})$ (Figure 2).

The inoculum from the waste water treatment plant displayed an inhibition of biogas production with no biogas production observed after an experimental run of 3 days. A reduced rate of lactic acid degradation was observed after 2 days, and GC analysis showed an accumulation of acetic and propionic acid. Propionic acid has been known to inhibit biogas production [43] which could explain the inhibition observed. The agriculture-based biogas plant inoculum showed almost complete utilization of lactic acid within the first day of the experimental run (shown in Appendix III) suggesting the presence of anaerobic bacteria with the ability to utilize the substrate. The standard reactor displayed a short lag phase compared to the other two inocula, with a reduced biogas production rate and lower total yield compared to the agriculture-based inoculum. This could be explained by a relatively low biomass, with a DM of only $1.8 \%$, compared to $4.9 \%$ and $3 \%$ with the agriculture-based plant and waste water treatment plant inocula respectively. GC analysis revealed lactic acid reduction to $0 \mathrm{~g} / \mathrm{L}$ after 3 days of experimental run.

Lactic acid was not a component of standard reactor feed; however the bacteria present in the standard reactor were able to convert starch present in the feed to lactic acid which was further utilized for biogas production. As lactic acid is an intermediate of sugar degradation [7] it is therefore reasonable to conclude that lactate is produced significantly during anaerobic digestion of carbohydraterich substrates.

\subsection{Biogas Production with Standard Reactor Inoculum Using Optimized Reactor Feed and Lactic Acid as a Sole Substrate}

Biogas production from the optimized feed for standard reactor was determined to compare it with that from a small quantity of lactic acid $(10 \mathrm{mM})$ and further with larger quantities (150 mM, $250 \mathrm{mM})$. Optimized reactor feed showing maxi-

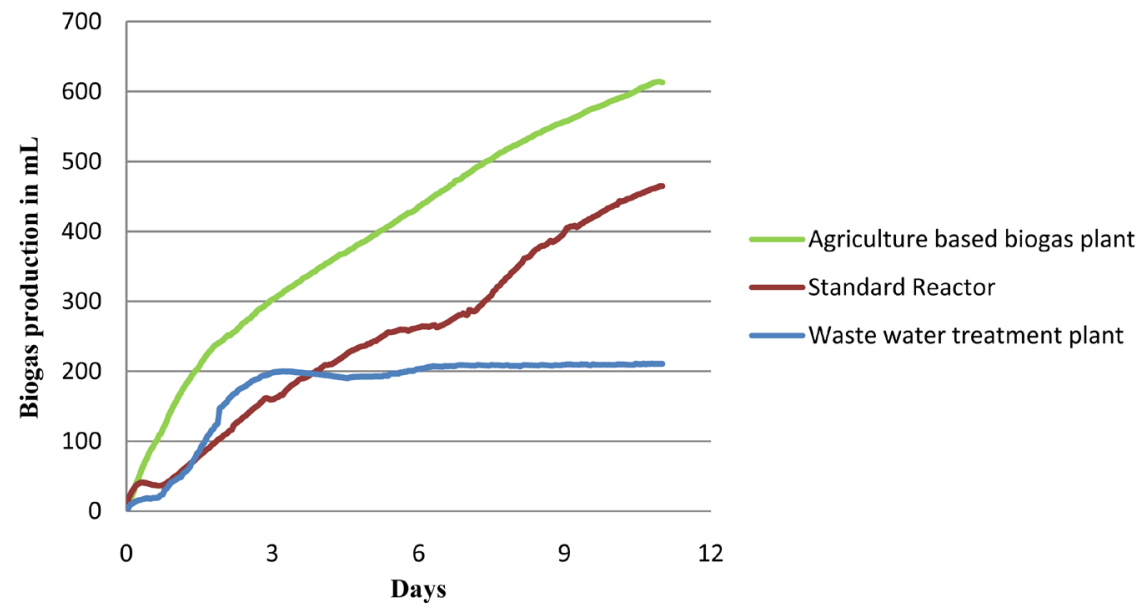

Figure 2. Biogas production with the different types of inocula tested with $10 \mathrm{mM}$ of lactic acid as substrate. Graph shows total biogas production with reference subtracted for each inoculum respectively. 
mal biogas production was found to be 3 times the concentration fed into the standard reactor. This energy source combination was comprised of starch (1.3 $\mathrm{g} / \mathrm{L})$ mixed with rapeseed oil $(2.0 \mathrm{~g} / \mathrm{L})$ and casein protein $(2.0 \mathrm{~g} / \mathrm{L})$. All other components of standard reactor feed remained unaltered.

Maximum biogas production was observed in the first hour for all treatments. Optimized feed produced nearly $48 \%$ more biogas than the reference treatment. It was found that the addition of just $10 \mathrm{mM}$ of lactic acid had a large impact on overall yield and production rate, producing almost $35 \%$ of the biogas of the optimized feed. A concentration of $150 \mathrm{mM}$ lactic acid resulted in the largest increase in total biogas yield. This exceeded the overall biogas production capacity of the reactor with optimized feed. Inhibition of biogas production was observed at $250 \mathrm{mM}$ (Figure 3).

Obviously, the bacteria in this standard reactor are able to utilize lactic acid, even at high concentrations (150 $\mathrm{mM})$. This is then rapidly converted rapidly to biogas. The considerable impact of lactic acid on biogas production and the overall system has also been demonstrated by the research of others, particularly in relation to silage-based anaerobic digesters [14]. With lactic acid resulting in such significant increases in biogas production, results of this study support our hypothesis that lactic acid indeed has a significant role in biogas production, and strongly influences biogas production rate and yield.

\section{Concluding Remarks}

Lactic acid is an intermediate of carbohydrate degradation and its presence can have a significant impact on biogas production. As a result of the ensilaging process, maize silage often contains substantial quantities of lactic acid in comparison to fresh maize. Additionally, the partial fermentation of silage and the hydrolyzed structure can result in an advantage over fresh maize for increased biogas yields. Experiments demonstrated a $45 \%$ increase in total biogas yield

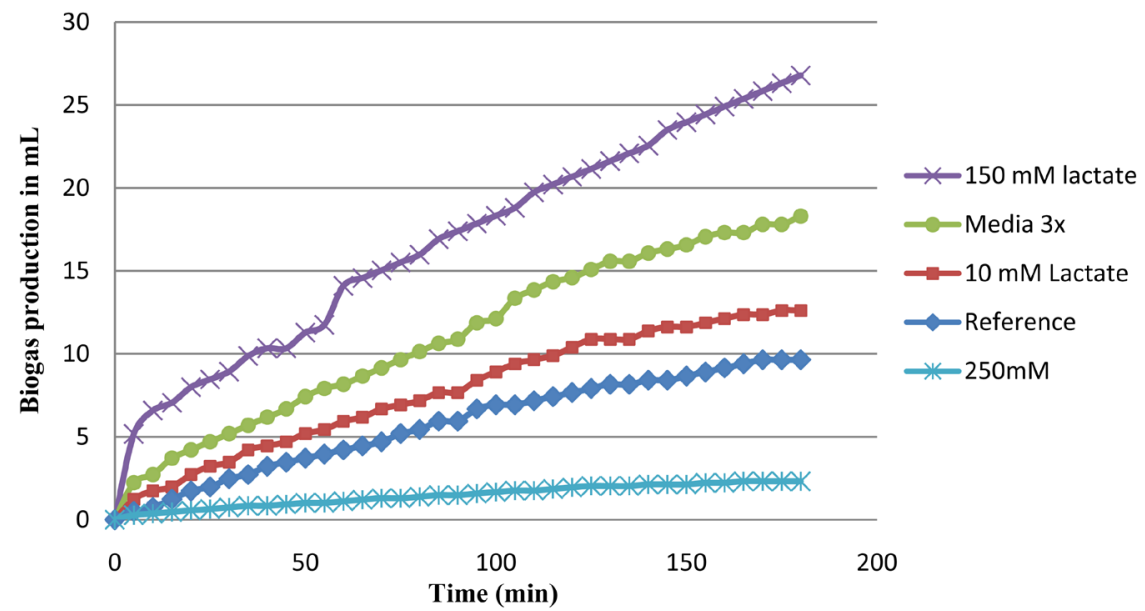

Figure 3. Activity of lactate compared to total activity of the media at saturation concentration. $10 \mathrm{mM}$ and $150 \mathrm{mM}$ lactic acid was compared to the total activity of media contents fed to the standard reactor. Pure inoculum was considered as reference. 
using maize silage over fresh maize, and lactic acid as a sole substrate can also result in an increased yield. This suggests that lactic acid plays an essential role in the increased total biogas production. These significant increases, however, were only observed in starter inocula which were previously exposed to lactic acid and that contained microbial communities able to utilize the intermediate. This finding is particularly important for facilities where lactic acid can be present in high quantities, such as silage, sugar and dairy-based biogas plants. Biogas reactor breakdowns have been reported in the past as a result of accumulation of lactic acid in their processes, therefore particular care must be taken when selecting a starter inoculum to ensure the utilization of this acid is possible. This research study could confirm that lactic acid is a key intermediate in biogas production, and provides rationale for its inclusion in predictive modeling and within the overall process. Our further research will focus on the impact of including lactate as a parameter in the Anaerobic Digestion Model No. 1 (ADM1) in influencing the prediction capability of the model.

\section{Acknowledgements}

This research was funded by Deutscher Akademischer Austauschdienst (DAAD. We thank Ingo Stein from EUTEC Institute, Hochschule Emden for his kind assistance. Engaged help of Candice Raeburn in proof-reading and improving the manuscript is gratefully acknowledged.

\section{References}

[1] Soares, E.V. and Soares, H.M. (2012) Bioremediation of Industrial Effluents Containing Heavy Metals Using Brewing Cells of Saccharomyces cerevisiae as a Green Technology: A Review. Environmental Science and Pollution Research, 19, 1066 1083. https://doi.org/10.1007/s11356-011-0671-5

[2] Boe, K. (2006) Online Monitoring and Control of the Biogas Process. Ph.D. Dissertation, Institute of Environment \& Resources, Technical University of Denmark, Copenhagen.

[3] Wieland, P. (2010) Biogas Production: Current States and Perspectives. Applied Microbiology and Biotechnology, 85, 849-860. https://doi.org/10.1007/s00253-009-2246-7

[4] Angelidaki, I., Madalena, A., Bolzonella, D., Borzacconi, L., Campos, L., et al. (2006) Anaerobic Biodegradation, Activity and Inhibition (ABAI). Task Group Meeting, 9-10 October 2006, Prague, Institute of Environmental \& Resources, Technical University of Denmark, Kgs., Lyngby.

[5] Biernacki, P., Steinigeweg, S., Borchert, A. and Uhlenhut, F. (2013) Application of Anaerobic Digestion Model No. 1 for Describing Anaerobic Digestion of Grass, Maize, Green Weed Silage, and Industrial Glycerine. Bioresource Technology, 127, 188-194.

[6] Batstone, D. and Keller, J. (2003) Industrial Applications of the IWA Anaerobic Digestion Model No. 1 (ADM1). Water Science and Technology, 47, 199-206.

[7] Sträuber, H., Schröder, M. and Kleinsteuber, S. (2012) Metabolic and Microbial Community Dynamics during the Hydrolytic and Acidogenic Fermentation in a Leach-Bed Process. Energy Sustainability and Society, 2, 13. 
http://www.energsustainsoc.com/content/2/1/13 https://doi.org/10.1186/2192-0567-2-13

[8] Jo, J.H., Jeon, C.O., Lee, D.S. and Park, J.M. (2007) Process Stability and Microbial Community Structure in Anaerobic Hydrogen-Producing Microflora from Food Waste Containing Kimchi. Journal of Biotechnology, 131, 300-308.

[9] Mrůzek, M. and Groda, B. (2011) Analysis of Biogas Production from Grass Silage, Depending on Its Quality. Acta Universitatis Agriculturae et Silviculturae Mendelianae Brunensis, 59, 239-246.

[10] Vourch, M., Balannec, B., Chaufer, B. and Dorange, G. (2005) Treatment of Dairy Industry Wastewater by Reverse Osmosis for Water Reuse. Desalination, 219, 190202.

[11] Soubes, M., Mux, L., Zunino, L. and Fernandez, A. (1989) Microbial Degradation of Lactate under Methanogenic Conditions. MIRCEN Journal of Applied Microbiology and Biotechnology, 5, 193-198. https://doi.org/10.1007/bf01741843

[12] Skiadas, I.V., Gavala, H.V. and Lyberatos, G. (2000) Modelling of the Periodic Anaerobic Baffled Reactor (PABR) Based on the Retaining Factor Concept. Water Research, 34, 3275-3736.

[13] Romli, M., Keller, J., Lee, P.J. and Greenfield, P.F. (1995) Modelling and Verification of a Two-Stage High-Rate Anaerobic Wastewater Treatment System Subjected to Shock Loads. Process Safety and Environmental Protection, 73, 151-154.

[14] Thamsiriroj, T., Nizami, A.S. and Murphy, J.D. (2012) Why Does Mono-Digestion of Grass Silage Fail in Long Term Operation? Applied Energy, 95, 64-76.

[15] Zhang, B., Cai, W.M and He, P.J. (2006) Influence of Lactic Acid on the Two-Phase Anaerobic Digestion of Kitchen Wastes. Journal of Environmental Sciences, 19, 244-249.

[16] Vervaeren, H., Hostyn, K., Ghekiere, G. and Willems, B. (2010) Biological Ensilage Additives as Pretreatment for Maize to Increase the Biogas Product. Renewable Energy, 35, 2089-2093.

[17] Haresign, W. and Cole, D.J.A. (1988) Meeting the Requirement of Beef Cattle in Forage Based Systems of Production. In: Recent Developments in Ruminant Nutrition, Butterwords, London, 352-353.

[18] Elferink, O., Krooneman, J., Gottschal, J.C., Spoelstra, S.F., Faber, F. and Driehuis, F. (2001) Anaerobic Conversion of Lactic Acid to Acetic Acid and 1,2-Propanediol by Lactobacillus buchneri. Applied Environmental Microbiology, 67, 125-132. https://doi.org/10.1128/AEM.67.1.125-132.2001

[19] Hao, L., Lü, F., He, P., Li, L. and Shao, L. (2011) Predominant Contribution of Syntrophic Acetate Oxidation to Thermophilic Methane Formation at High Acetate Concentrations. Environmental Science and Technology, 45, 508-513. https://doi.org/10.1021/es102228v

[20] Rojas, C., Fang, S., Uhlenhut, F., Stein, I., Borchert, A. and Schlaak, M. (2010) Stirring and Biomass Starter Influences the Anaerobic Digestion of Different Substrates for Biogas Production. Engineering in Life Sciences, 10, 339-347. https://doi.org/10.1002/elsc.200900107

[21] Karakashev, D., Batstone, D.J. and Angelidaki, I. (2005) Influence of Environmental Conditions on Methanogenic Compositions in Anaerobic Biogas Reactors. Applied Environmental Microbiology, 71, 331-338. https://doi.org/10.1128/AEM.71.1.331-338.2005

[22] Hobson, P.N. and Wheatley, A.D. (1993) Anaerobic Digestion, Modern Theory and Practice. Elsevier Science Publishers, Ltd., Essex, UK. 
[23] Demirel, B. and Scherer, P. (2008) The Roles of Acetotrophic and Hydrogenotrophic Methanogens during Anaerobic Conversion of Biomass to Methane: A Review. Reviews on Environmental Science and Biotechnology, 7, 173-190. https://doi.org/10.1007/s11157-008-9131-1

[24] Lopes, W.S., Leite, V.D. and Prasad, S. (2004) Influence of Inoculum on Performance of Anaerobic Reactors for Treating Municipal Solid Waste. Bioresource Technology, 94, 261-266.

[25] EWE Biogas GmbH \& Co. KG. Wittmund Biogas Power Plant: Important Data at a Glance. http://www.ewe-biogas.de/english/index_28.php

[26] Papenburg Waste Water Treatment Plant. http://papenburg.de/index.php?sid=m77hvvgnrgr4tfuhg8jjlf03g5m35ng4\&m $=1$ \&hi $\mathrm{d}=376 \&$ bid $=2981$

[27] Angelidaki, I. and Sanders, W. (2004) Assessment of the Anaerobic Biodegradability of Macropollutants. Reviews in Environmental Science and Biotechnology, 3, 117 129. https://doi.org/10.1007/s11157-004-2502-3

[28] Verein Deutscher Ingenieure (VDI) (2006) Fermentation of Organic Material. Characterization of the Substrate, Sampling, Collection of Material Data, Fermentation Tests. Verein Deutscher Ingenieure, Düsseldorf.

[29] Amon, T., Amon, B., Kryvoruchko, V., Zollitsch, W., Mayer, K. and Gruber, L. (2007) Biogas Production from Maize and Dairy Cattle Manure-Influence of Biomass Composition on the Methane Yield. Agriculture Ecosystem and Environment, 118, 173-182.

[30] Dash, A. (2010) Efficiency Study of Two Wetland Treatment Systems at Bhubaneswar, India. The Bioscan, 3, 701-711.

[31] Haydersah, J., Chevallier, I., Rochette, I., Mouquet-Rivier, C., Picq, C., et al. (2012) Fermentation by Amylolytic Lactic Acid Bacteria and Consequences for Starch Digestibility of Plantain, Breadfruit, and Sweet Potato Flours. Journal of Food Science, 77, M466-M472. https://doi.org/10.1111/j.1750-3841.2012.02811.x

[32] Hofvendahl, K., Aêkerberg, C., Zacchi, G.B. and Haègerdal, H. (1999) Simultaneous Enzymatic Wheat Starch Saccharification and Fermentation to Lactic Acid by Lactococcus lactis. Applied Microbiology and Biotechnology, 52, 163-169. https://doi.org/10.1007/s002530051503

[33] Satpathy, P., Steinigeweg, S., Cypionka, H. and Engelen, B. (2016) Different Substrates and Starter Inocula Govern Microbial Community Structures in Biogas Reactors. Environmental Technology, 37, 1441-1450. https://doi.org/10.1080/09593330.2015.1118559

[34] Herrmann, C., Heiermann, M. and Idler, C. (2011) Effects of Ensiling, Silage Additives and Storage Period on Methane Formation of Biogas Crops. Bioresource Technology, 102, 5153-5161.

[35] Menardo, S., Balsari, P., Tabacco, E. and Borreani, G. (2015) Effect of Conservation Time and the Addition of Lactic Acid Bacteria on the Biogas and Methane Production of Corn Stalk Silage. Bioenergy Research, 8, 1810-1823.

[36] McEniry, J., Allen, E., Murphy, J.D. and O'Kiely, P. (2014) Grass for Biogas Production: The Impact of Silage Fermentation Characteristics on Methane Yield in Two Contrasting Biomethane Potential Test Systems. Renewable Energy, 63, 524-530.

[37] Dearman, B., Marschner, P. and Bentham, R.H. (2006) Methane Production and Microbial Community Structure in Single-Stage Batch and Sequential Batch Systems Anaerobically Co-Digesting Food Waste and Biosolids. Applied Microbiology and Biotechnology, 69, 589-596. https://doi.org/10.1007/s00253-005-0076-9 
[38] Stroot, P.G., McMahon, K.D., Mackie, R.I. and Raskin, L. (2001) Anaerobic Codigestion of Municipal Solid Waste and Biosolids under Various Mixing Conditions -I. Digester Performance. Water Research, 35, 1804-1816.

[39] Batstone, D.J., Keller, J., Angelidaki, I., Kalyuzhnyi, S.V., Pavlostathis, S.G., et al. (2002) Anaerobic Digestion Model No. 1. International Water Association, London.

[40] Kreuger, E., Nges, A.I. and Björnsson, L. (2011) Ensiling of Crops for Biogas Production: Effects on Methane Yield and Total Solids Determination. Biotechnology and Biofuels, 4, 6-8.

[41] Zubr, J. (1986) Methanogenic Fermentation of Fresh and Ensiled Plant Materials. Biomass, 111, 159-171.

[42] Hutňan, M., Špalková, V., Bodík, I., Kolesárová, N. and Lazor, M. (2010) Biogas Production from Maize Grains and Maize Silage. Polish Journal of Environmental Studies, 19, 323-329.

[43] Fang, H.H.P. and Yu, H.Q. (2002) Mesophilic Acidification of Gelatinaceous Wastewater. Journal of Biotechnology, 93, 99-108. 


\section{Appendix I}

Acetic acid content when mixed with the two substrates: maize, silage and without substrates(reference) in (a) Agricultural waste based reactor (b) Waste water treatment plant and (c) Standard reactor.
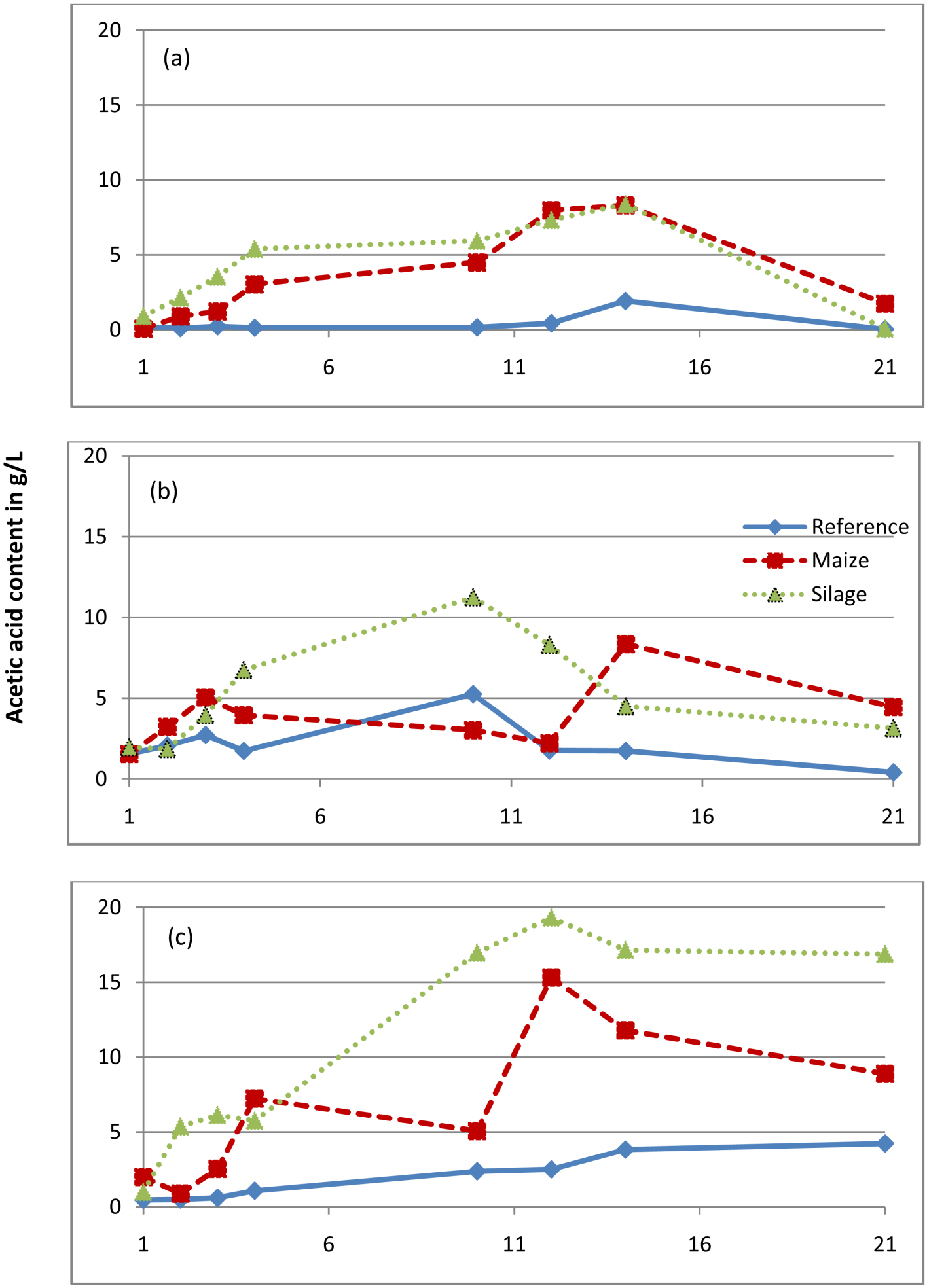

Days 


\section{Appendix II}

Organic acid content in the pure inoculum from (a) Agriculture-based biogas reactor (b) Waste water treatment plant and (c) Standard reactor.

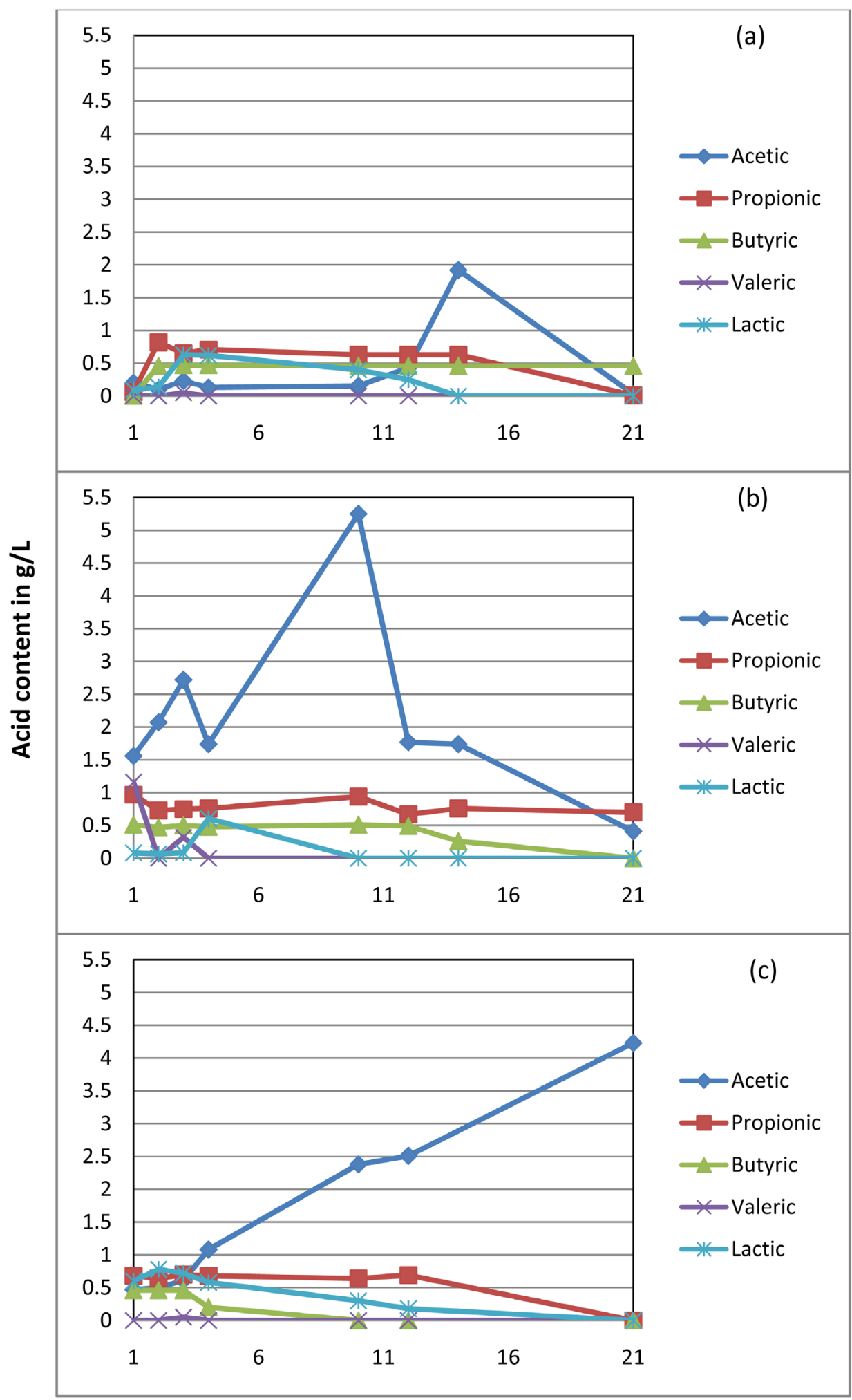

Days 


\section{Appendix III}

Degradation of $10 \mathrm{mM}$ lactic acid used as a solo substrate with the different inocula during batch experiments.

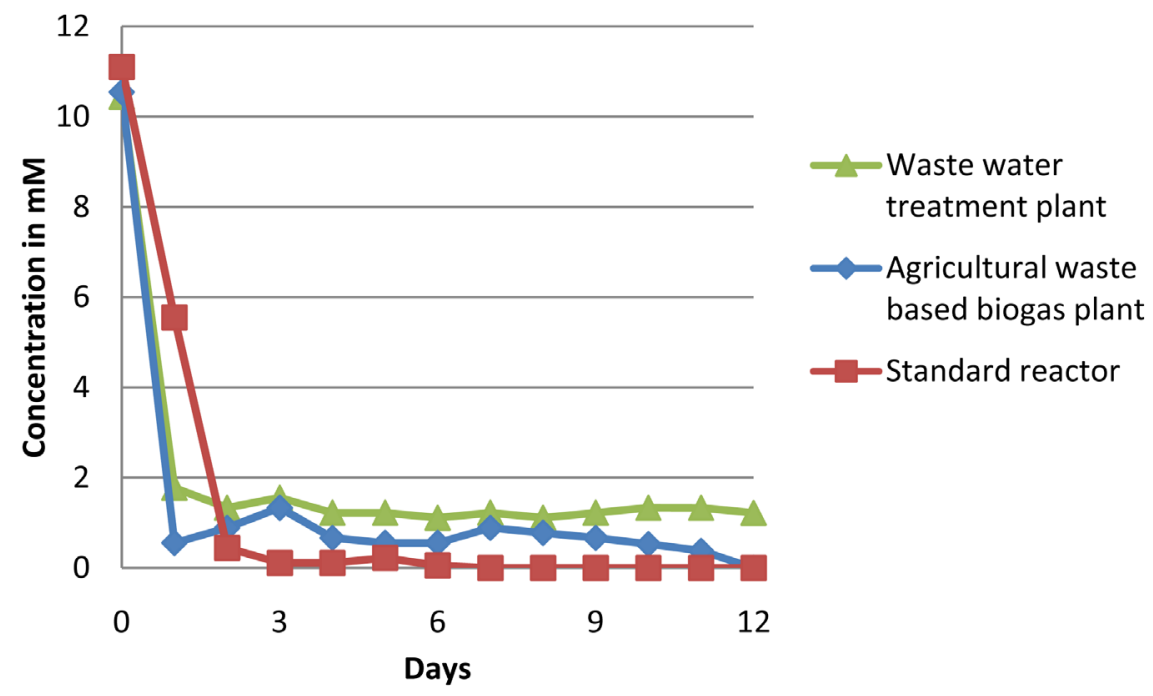

Submit or recommend next manuscript to SCIRP and we will provide best service for you:

Accepting pre-submission inquiries through Email, Facebook, LinkedIn, Twitter, etc. A wide selection of journals (inclusive of 9 subjects, more than 200 journals)

Providing 24-hour high-quality service

User-friendly online submission system

Fair and swift peer-review system

Efficient typesetting and proofreading procedure

Display of the result of downloads and visits, as well as the number of cited articles Maximum dissemination of your research work

Submit your manuscript at: http://papersubmission.scirp.org/

Or contact aim@scirp.org 